\title{
Nested PCR detection of microscopic life-stages of laminarian macroalgae and comparison with adult forms along intertidal height gradients
}

\author{
Caroline H. Fox, Andrew K. Swanson* \\ Department of Biology, Millis Hall, Case Western Reserve University, Cleveland, Ohio 44106, USA
}

\begin{abstract}
Recruitment of kelp species (Laminariales) to rocky marine habitats relies on the prior establishment of microscopic life-stages (zoospores, gametophytes, gametes and microscopic sporophytes). Unlike macroscopic sporophyte stages of kelp, microscopic life-stages have proved difficult to detect and identify in their natural habitat. Using a species-specific PCR-based assay, we developed a method to detect putative microscopic life-stages of 2 northeast Pacific kelp species, Nereocystis luetkeana (Mertens) Postels et Ruprecht and Hedophyllum sessile (C. Agardh) Setchell, from rocky intertidal substrate samples. Species-specific primers were evaluated for specificity and sensitivity. Comparisons of nested and unnested PCR were performed for both species. Nested PCR was used to screen for target species present on rocks obtained along an intertidal height gradient $(0.0$ to $3.5 \mathrm{~m}$ Lowest Low Water [LLW]) from 2 sites at monthly intervals in summer 2005. Vertical distribution patterns of the putative microscopic life-stages and the macroscopic sporophyte form were compared at both sites. Putative microscopic life-stages of $N$. luetkeana were detected at both sites and displayed a widespread vertical distribution with no clear spatial or temporal relationship. In comparison, $H$. sessile putative microscopic life-stage distribution was much more spatially restricted, showing a similar distribution to the macroscopic sporophyte. This study demonstrates the sensitivity, specificity and validity of utilizing molecular techniques to describe the distribution of microscopic life-stages of certain kelp species.
\end{abstract}

KEY WORDS: Kelp $\cdot$ Nested PCR $\cdot$ Microscopic lifestages $\cdot$ ITS rDNA $\cdot$ Intertidal

Resale or republication not permitted without written consent of the publisher

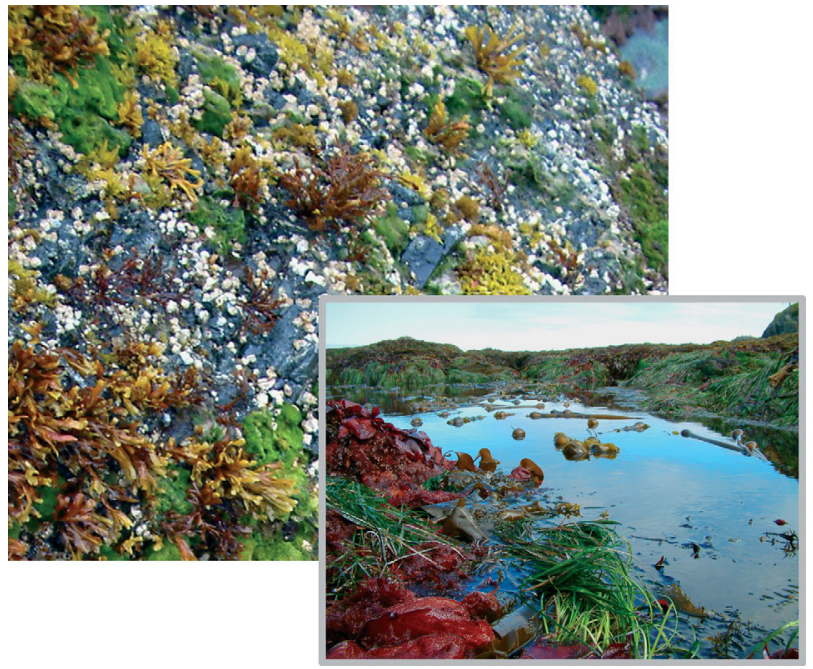

Microscopic life-stages of kelp are difficult to identify in nature. A nested PCR assay was used to detect and monitor the distribution of microscopic life-stages of 2 intertidal Pacific kelp species, Nereocystis luetkeana and Hedophyllum sessile. This technique is important for assessing zonation patterns, persistence and recovery of kelp species on rocky substrates.

Photos: Caroline H. Fox \& Robert J. J. Davey

\section{INTRODUCTION}

Members of the order Laminariales, often dominant in rocky nearshore and intertidal zones of temperate and polar seas, undergo lifecycles that involve the alternation of heteromorphic generations (reviewed in Dayton 1985, Foster \& Schiel 1985, Schiel \& Foster 1986, Steneck et al. 2002). Development to the diploid macroscopic sporophyte stage relies on a number of microscopic life-stages (zoospores, gametophytes, 
gametes and microscopic sporophytes) and, while identification within the Laminariales is largely based upon morphological characters of the macroscopic sporophyte (Setchell \& Gardner 1925), species identification of microscopic life-stages has proved difficult. Currently, there exists no taxonomy for Laminariales gametophytes (Garbary et al. 1999), embryonic sporophytes or settled zoospores that can be used to identify organisms to species, genus or even family levels, although species discrimination of planktonic kelp zoospores is possible (Graham 1999, Graham \& Mitchell 1999). Consequently, very little is known about the ecology of post-settlement kelp microscopic life-stages, despite their purported influence.

Microscopic life-stages of marine algae may play crucial roles in determining population persistence, distribution, recovery and dynamics. Referred to as 'banks of microscopic forms' by Chapman (1986), microscopic life-stages are thought to function analogously to terrestrial seedbanks (Edwards 2000), i.e. they are capable of persisting in environmental conditions too stressful for the large macrophyte form (Anderson 1982, Santelices 1990, Hoffman \& Santelices 1991, Kinlan et al. 2003). Experimental evidence suggests that microscopic life-stages of marine algae may enhance recruitment (Edwards 2000), persistence (Edwards 2000, Kinlan et al. 2003), contribute to recovery following disturbance (Santelices 1990, Santelices et al. 1995, Blanchette 1996, Edwards 2000, Kinlan et al. 2003) and determine the presence of the macroscopic form (Graham 1996, Ladah et al. 1999, Edwards 2000, Swanson \& Druehl 2000). More specifically, studies indicate that sensitivities of microscopic life-stages of kelp are related to vertical zonation patterns of the macroscopic sporophyte form (Swanson \& Druehl 2000, Wiencke et al. 2000, 2004, 2006, Roleda et al. 2005), although efforts to characterize natural microscopic life-stage assemblages along tidal height gradients have been hampered by identification constraints.

In situ research involving post-settlement microscopic life-stages of Laminariales and closely related orders generally involves out-planting laboratory cultured microscopic life-stages (e.g. Hsiao \& Druehl 1973, Reed 1990, Graham 1996, Edwards 2000, Wiencke et al. 2006), monitoring macroscopic recruitment on natural, artificial or manipulated substrates to infer information regarding microscopic life-stages (e.g. Druehl \& Hsiao 1977, Reed et al. 1988, Reed 1990, Graham 1996, Reed et al. 1997, Edwards 2000) and/or identification of microscopic life-stages to the lowest taxonomic group possible (e.g. Laminariales; Garbary et al. 1999). Recently, a conventional PCR-based approach was used to identify extrageneric epiphytic and endophytic kelp gametophytes inhabiting the thalli of Lessoniopsis littoralis (Lane \& Saunders 2005).
A wide array of PCR-based molecular tools have been used to detect, monitor and map the distribution of microorganisms in a range of natural and manipulated environments. Of these tools, nested PCR is a highly sensitive and specific technology, often used to detect one or more species in environmental samples. For example, arbuscular mycorrhizal fungi in plant roots (van Tuinen et al. 1998), pathenogenic fungi in plant tissues (Zhang et al. 2005), seastar larvae in ballast water (Deagle et al. 2003) and a toxic dinoflagellate in ballast and estuarine samples (Patil et al. 2005) were detected using nested PCR protocols. Using a similar approach, we developed 2 nested PCR protocols for the detection of Hedophyllum sessile (C. Agardh) Setchell and Nereocystis luetkeana (Mertens) Postels et Ruprecht from epilithic and endolithic biofilm communities inhabiting natural intertidal rock substrates.

Using a combination of our nested PCR detection protocol and intertidal quadrat surveys, we described and compared the spatial and temporal distribution of macroscopic and putative microscopic life-stages of Nereocystis luetkeana and Hedophyllum sessile along a vertical tidal height gradient at 2 locations in Barkley Sound, British Columbia, Canada, that differ in wave exposure and presence of macroscopic sporophytes. $N$. luetkeana, considered an annual but often surviving longer, is a common subtidal canopy-forming species that may grow to over $10 \mathrm{~m}$ in length. In contrast, perennial $H$. sessile sporophytes are small prostrate forms lacking a stipe and are generally found in the mid- and low intertidal. Based on the absence of macroscopic sporophytes at the relatively wave sheltered site, no microscopic life-stages were predicted to occur. In comparison, at the site of higher wave exposure, macroscopic forms of both species persisted, and we predicted that putative microscopic life-stages would be present on intertidal rock. However, predicting the distribution of putative microscopic life-stages along a tidal height gradient is impeded by a lack of prior knowledge regarding specific tolerances of microscopic life-stages to environmental parameters, necessary sampling intensity to capture the distributions of the microscopic forms and insight into the time required for DNA degradation upon microscopic lifestage cell death. Nonetheless, given the degree of wave action and turbulence at the exposed site and the observation of reproductive (i.e. presence of sori) sporophytes throughout the sampling period, we predicted that putative microscopic life-stages of both species would be detected throughout the tidal height gradient. To the best of our knowledge, this study represents the first attempt to directly detect and characterize the distribution of putative microscopic life-stages of kelp inhabiting natural intertidal substrates. 


\section{MATERIALS AND METHODS}

Two sites (Bluestone Point and Dixon Island) located in Barkley Sound, British Columbia, Canada, were selected. The maximum predicted tidal flux in this region is approximately $4.0 \mathrm{~m}$. Both sites have a northwest aspect and host visibly different macroalgal communities. Bluestone Point $\left(48^{\circ} 49^{\prime} \mathrm{N}, 125^{\circ} 09^{\prime} \mathrm{W}\right)$ is more proximal to the open ocean and experiences high wave action. Dixon Island $\left(48^{\circ} 51^{\prime} \mathrm{N}, 125^{\circ} 07^{\prime} \mathrm{W}\right)$, located $4.6 \mathrm{~km}$ from Bluestone Point and further from the open ocean, has a small rock outcropping just offshore that buffers wave action. Rock substrate in this region is identified as Westcoast Complex from the Upper Paleozoic and/or Triassic or Jurassic (Muller 1982). At Dixon Island and Bluestone Point, the Westcoast Complex is characterized as intrusive igneous rock predominantly composed of granite, granodiorite, quartz diorite and diorite (Van der FlierKeller \& McMillan 1987, J. Fox pers. comm.).

Three permanent vertical transect lines, approximately $5 \mathrm{~m}$ apart, were established at both sites and stainless steel screws were affixed to the substrate at every $0.5 \mathrm{~m}$ tidal height (Lowest Low Water [LLW]) from 0.0 to $3.5 \mathrm{~m}$. During each low tide series in summer 2005 (May 24 to 25, June 23 to 25, July 20 to 21 and August 19 to 20), $0.25 \mathrm{~m}^{2}$ quadrat surveys were performed at each $0.5 \mathrm{~m}$ tidal height along all 3 transects in order to monitor distributions (presence/ absence) of macroscopic sporophyte Laminariales species $(\mathrm{n}=24)$. At each site, 3 rock samples were collected at $0.5 \mathrm{~m}$ tidal height intervals along the middle transect using 2 geological hammers. Rock samples were selected for their visible absence of any macroscopic Laminariales, other algal species, barnacles and mussels with one notable exception. In the lower intertidal, the occurrence of 'bare' rock is fairly uncommon, and encrusting coralline algae were frequently included in the rock substrate sample. Rock samples were placed in sterile bags and transported at ambient temperatures in the shade to the laboratory for $\mathrm{ca} .1 \mathrm{~h}$ until frozen at $-80^{\circ} \mathrm{C}$.

Environmental DNA isolation. Epilithic and endolithic biofilm communities of the rock substrates were sampled by grinding the rock surfaces with a Durabuilt ${ }^{\mathrm{TM}}$ rotary tool with an attached carbide drill tip (Dremel ${ }^{\mathrm{TM}} 3.2 \mathrm{~mm}$ tungsten carbide cutter). Due to heat production by the drill bit and potential sample degradation at room temperatures, grinding was performed while the sample was immersed in liquid nitrogen. A small surface area (ca. $4.15 \mathrm{~cm}^{2}$ ) was ground until bare rock was observed (i.e. grinding the epilithic biofilm); it was subsequently ground 5 additional times to sample similar depths of the endolithic biofilm and the resulting powder collected. All equipment was either flame sterilized or autoclaved between samples, with the exception of the rotary wand, which was rinsed repeatedly with ethanol and sterile water and then flame dried.

Powder from replicate $(n=3)$ samples was pooled for DNA extraction using the FastDNA ${ }^{\circledR}$ Spin kit for soil (Q-Biogene) with the optional 15 min extended spin included and the use of a vortexer (Fisher Scientific Mini Vortexer) set on 6 for 2 min instead of a beadbeater. DNA was eluted in $70 \mu \mathrm{l}$ of purified water, vacuum-dried for shipping and stored at $-20^{\circ} \mathrm{C}$ until resuspended in $50 \mu \mathrm{l}$ TE $(10 \mathrm{mM}$ Tris- $\mathrm{HCl} \mathrm{pH} 7.4$, 1 mM EDTA) for use.

Macroscopic sporophyte DNA isolation. Sporophyte tissues were obtained from meristematic regions of the youngest available sporophytes collected in and around Barkley Sound and frozen at $-80^{\circ} \mathrm{C}$ until use. All sporophyte tissues were extracted using a modified CTAB-Proteinase-K DNA extraction protocol (modified from Ausubel et al. 1987, Doyle \& Doyle 1990, Antoine \& Fleurence 2003). Sporophyte tissues were immersed in liquid nitrogen and ground with a mortar and pestle. Approximately $100 \mu \mathrm{l}$ of ground tissue was incubated for $1 \mathrm{~h}$ at $65^{\circ} \mathrm{C}$ in CTAB extraction buffer (sample to buffer ratio (w/v) 1:4, 2\% (w/v) CTAB, $1 \%(\mathrm{w} / \mathrm{v})$ polyvinylpyrolidone, $1 \%(\mathrm{v} / \mathrm{v}) \beta$-mercaptoethanol, $100 \mathrm{mM}$ TrisCl pH 8.0, 20 mM EDTA pH 8.0 and $1.4 \mathrm{M} \mathrm{NaCl}$ ). Proteinase $\mathrm{K}$ was added (final concentration $1 \mathrm{mg} \mathrm{ml}^{-1}$ ) and the mixture was incubated at $50^{\circ} \mathrm{C}$ for $1 \mathrm{~h}$. The solution was extracted with phenol/chloroform/isoamyl (25:24:1 v/v/v; PCI), centrifuged $(1600 \times g, 10 \mathrm{~min}$, but occasionally longer if debris in the supernatant remained) and the aqueous layer recovered. The recovered aqueous layer was precipitated in $2 / 3$ volume of cold isopropanol overnight at $-20^{\circ} \mathrm{C}$. Precipitated DNA was centrifuged until a loose pellet formed $(700 \times g)$. The recovered pellet was rinsed with wash buffer $(76 \%(\mathrm{v} / \mathrm{v})$ ethanol, $10 \mathrm{mM}$ ammonium acetate), left at room temperature for $1 \mathrm{~h}$, pelleted again $(1600 \times g, 10 \mathrm{~min})$, air dried and dissolved in TE buffer. A final purification step involved a $2 \times$ dilution with TE and $7.5 \mathrm{M}$ ammonium acetate added to a final concentration of $2.5 \mathrm{M}$. Cold ethanol ( 2.5 volumes) was added to precipitate DNA; this was then centrifuged $(10000 \times g, 10 \mathrm{~min})$ and the pellet recovered and resuspended in TE.

Cultures. Gametophyte cultures were obtained from reproductive adults collected near study sites in Barkley Sound. Briefly, sori were excised from the thalli, scrubbed with paper towels, rinsed in a $0.07 \%$ solution of iodine in sterile seawater, rinsed 5 additional times in sterile seawater, blotted dry and left at $12^{\circ} \mathrm{C}$ for 1 to $2 \mathrm{~h}$ while wrapped in paper towels. Zoospores were released in sterile seawater for approximately $1 \mathrm{~h}$, strained through cheesecloth and quantified with a haemocytometer. Cultures with an initial concentration 
of 3000 swimming zoospores $\mathrm{ml}^{-1}$ were grown in aerated glass jars with enriched seawater medium $(1 \mathrm{ml}$ each $A$ and $B$ algal nutrients in 11 sterile seawater; Fritz A and B f/2 Algae Food, Fritz Industries) under long day (18:6 h light:dark) light conditions for $60 \mathrm{~d}$. Before harvesting, gametophytes were examined under a microscope to ensure that additional life-stages had not yet developed. Gametophytes were harvested by scraping jar sides and bottoms and then collected on sterile filter paper and dried at $37^{\circ} \mathrm{C}$ for $12 \mathrm{~h}$ prior to weighing. Dry gametophyte tissues were ground in a mortar and pestle and DNA was isolated from $10 \mathrm{mg}$ of each species using the same protocol as that for the environmental rock substrate samples. DNA extracts were electrophoresed in $1.5 \%$ agarose gels stained with ethidium bromide $\left(0.2 \mu \mathrm{g} \mathrm{ml}^{-1}\right)$ and quantified using a Lambda HindIII standard and TotalLab ${ }^{\mathrm{TM}}$ software (Nonlinear Dynamics).

Primer design. Sequences of rDNA ITS1, 5.8S and ITS2 regions from 28 kelp species sequences were aligned using ClustalW (European Bioinformatics Institute). Regions of species dissimilarity in the ITS1 and ITS2 regions were chosen as potential primer sites. Primers in unique regions of target species were designed to have low 3' GC content, high speciesspecific affinity and melting temperatures within $5^{\circ} \mathrm{C}$ of the other primer. Inner primers were also designed to have melting temperatures that were significantly higher than the outer, first round primer pair, as a means of deactivating those primers from second round PCR activity.

Specificity. NCBI (National Center for Biotechnology Information) BLAST searches were performed on po- tential Nereocystis luetkeana and Hedophyllum sessile species primer pairs to ensure their specificity. To further increase confidence in their specificity, speciesspecific primers were tested against 25 non-target DNA samples isolated from algal sporophyte DNA (Phaeophyceae, Chlorophyceae and Bangiophyceae).

All reactions for the specificity assay were performed on a MyCycler Thermocycler (Bio-Rad Laboratories) using species-specific primer pairs (Nereocystis luetkeana F/R2 and Hedophyllum sessile F2/R2) (Table 1) with optimized thermocycler temperatures and settings (Table 2). PCR reactions (25 $\mu \mathrm{l}$ volume) contained $2 \mu$ template DNA $\left(10^{1}, 10^{2}\right.$, and $10^{3}$ dilutions), $5 \mu$ l Genereleaser ${ }^{\mathrm{TM}}$ (Bioventures), $1 \times$ buffer (600 mM Tris- $\mathrm{SO}_{4}$ [pH 8.9], $180 \mathrm{mM}$ ammonium sulfate), $2 \mathrm{mM}$ magnesium chloride, $200 \mu \mathrm{M}$ each dNTP, $0.4 \mu \mathrm{M}$ each primer, and $0.875 \mathrm{U}$ Platinum High Fidelity Taq polymerase (Invitrogen) overlaid with mineral oil. A preliminary thermocycler run with Genereleaser $^{\mathrm{TM}}$, template DNA and mineral oil was performed according to manufacturer's instructions. Negative and positive controls were included in each thermocycler run.

As a positive control for sporophyte-derived DNA susceptibility to amplification, all Laminariales species were amplified using KG4 (Druehl et al. 2005, modified from Tai et al. 2001) and modified ITSP1 (modified from Tai et al. 2001) primers using identical PCR reagents as described above. All non-Laminariales sporophyte tissues were amplified using universal eukaryotic primers that target the $18 \mathrm{~S}$ gene region (van Hannen et al. 1998). Thermocycler conditions for the universal eukaryotic primers followed van Hannen et al. (1999).

Table 1. Primer sequence, target and source information for unnested and nested PCR detection of Nereocystis luetkeana and Hedophyllum sessile

\begin{tabular}{|llll|}
\hline Primer name & Primer sequence 5'- 3' $^{\prime}$ & Target & Source \\
\hline KG4 & CTTTTCCTCCGCTTAGTTATATG & 25S & Druehl et al. (2005) modified from Tai et al. (2001) \\
Modified ITSP1 & GGAAGGTGAAGTCGTAACAAGG & 18S & Modified from Tai et al. (2001) \\
N. luetkeana F & AGCTCAATCAAGCGCTCTCG & ITS1 & Druehl et al. (2005) \\
N. luetkeana R2 & GTGGTGTACGGATTCCAGCAG & ITS2 & Present study \\
H. sessile F2 & GGTTCCTGCGGCTCTGTCCG & ITS1 & Present study \\
H. sessile R2 & AATGAGGCAGGCGGGCCT & ITS2 & Present study \\
\hline
\end{tabular}

Table 2. PCR thermocycler conditions for unnested and nested PCR detection of Nereocystis luetkeana and Hedophyllum sessile. See Table 1 for sources

\begin{tabular}{|c|c|c|c|c|c|c|}
\hline \multirow[t]{2}{*}{ Primer pair } & \multirow{2}{*}{$\begin{array}{c}\text { Initial } \\
\text { denature }\end{array}$} & \multicolumn{3}{|c|}{ - Cycle conditions } & \multirow{2}{*}{$\begin{array}{c}\text { Final } \\
\text { extension }\end{array}$} & \multirow{2}{*}{$\begin{array}{c}\text { Cycle } \\
\text { no. }\end{array}$} \\
\hline & & Denature & Anneal & Extension & & \\
\hline Modified ITSP1/KG4 & $94^{\circ}, 3 \mathrm{~min}$ & $94^{\circ}, 50 \mathrm{~s}$ & $63.6^{\circ}, 50 \mathrm{~s}$ & $72^{\circ}, 50 \mathrm{~s}$ & $72^{\circ}, 8 \mathrm{~min}$ & 38 \\
\hline N. luetkeana F/R2 & $94^{\circ}, 3 \mathrm{~min}$ & $94^{\circ}, 50 \mathrm{~s}$ & $69.1^{\circ}, 50 \mathrm{~s}$ & $72^{\circ}, 50 \mathrm{~s}$ & $72^{\circ}, 8 \mathrm{~min}$ & 35 \\
\hline H. sessile F2/R2 & $94^{\circ}, 3 \mathrm{~min}$ & $94^{\circ}, 50 \mathrm{~s}$ & $71.1^{\circ}, 50 \mathrm{~s}$ & $72^{\circ}, 50 \mathrm{~s}$ & $72^{\circ}, 8 \mathrm{~min}$ & 35 \\
\hline
\end{tabular}


Sensitivity. Unnested and nested PCR were performed on pure gametophyte-derived Nereocystis luetkeana and Hedophyllum sessile DNA in order to determine sensitivity limits. In the unnested protocol, $1 \mu \mathrm{l}$ of $10 \mathrm{ng}, 1 \mathrm{ng}, 100 \mathrm{pg}, 10 \mathrm{pg}, 1 \mathrm{pg}, 100 \mathrm{fg}, 10 \mathrm{fg}$ and 1 fg gametophyte-derived DNA were amplified using the species-specific inner primer pairs $(N$. luetkeana F/R2 and $H$. sessile F2/R2) (Table 1). In the nested protocol, the first round of PCR utilized outer modified ITSP1 and KG4 primers (Table 1). Using $1 \mu$ of the first-round PCR product as a template, the second round PCR reactions were performed using the species-specific primers following outlined thermocycler settings (Table 2). Nested sensitivity reactions were carried out with undiluted first round PCR product as template, with the exception of nested 10 and $1 \mathrm{ng} H$. sessile reactions, which were carried out using 1:50 product dilutions due to the formation of spurious PCR products in the final reaction. All reactions were performed in $25 \mu$ l volumes that contained $1 \mu$ template DNA $\left(10^{1}, 10^{2}\right.$, and $10^{3}$ dilutions), $1 \times$ buffer $(600 \mathrm{mM}$ Tris- $\mathrm{SO}_{4}$ [pH 8.9], $180 \mathrm{mM}$ ammonium sulfate), $2 \mathrm{mM}$ magnesium chloride, $200 \mu \mathrm{M}$ each dNTP, $0.4 \mu \mathrm{M}$ each primer, and $0.875 \mathrm{U}$ Platinum High Fidelity Taq polymerase.

Environmental assays. Screening for the presence of Nereocystis luetkeana and Hedophyllum sessile in mixed species genomic DNA isolated from intertidal rocks was performed using nested PCR. Crude DNA extracts were subjected to amplification for the first round of PCR with the Laminarialesconserved, modified ITSP1 and KG4 primers (Table 1). PCR reactions using $2 \mu \mathrm{l}$ of 4 dilutions $\left(10^{0}, 10^{1}, 10^{2}\right.$ and $\left.10^{3}\right)$ of DNA extracts were performed with reaction components and thermocycler settings described for the sensitivity protocol. For the second round, all 4 dilutions were pooled and nested PCR performed using either $N$. luetkeana or $H$. sessile inner primer pairs (Table 1) and $1 \mu \mathrm{l}$ of the pooled PCR product as template. PCR reaction components were identical to the first round, and all thermocycler runs contained negative and positive controls. Reaction products were visualized in $1.5 \%$ agarose gel stained with ethidium bromide $\left(0.2 \mu \mathrm{g} \mathrm{ml}^{-1}\right)$. To validate the technique by confirming species detection, positive reactions from rock samples collected from Bluestone Point in May and June 2005 were purified using the QIAQuick PCR Purification Kit (Qiagen) and commercially sequenced (Cleveland Genomics) using forward primers. Recovered sequences were compared with in-lab and published sequences of $N$. luetkeana or $H$. sessile. All subsequent screening identity for both species was confirmed by PCR fragment length.

\section{RESULTS}

Nereocystis luetkeana F/R2 and Hedophyllum sessile F2/R2 primer pairs exhibited specificity for their target species using NCBI BLAST searches and empirical tests with 25 different non-target algal species (Fig. 1). Both species primer pairs also amplified DNA from target species gametophyte- and sporophyte-derived DNA (Figs. 1 \& 2). Fragment lengths obtained from inner primer pairs were $412 \mathrm{bp}$ and approximately $575 \mathrm{bp}$ for $H$. sessile and $N$. luetkeana, respectively.

The use of nested PCR resulted in 100 and 1000 times greater detection sensitivity than unnested PCR for

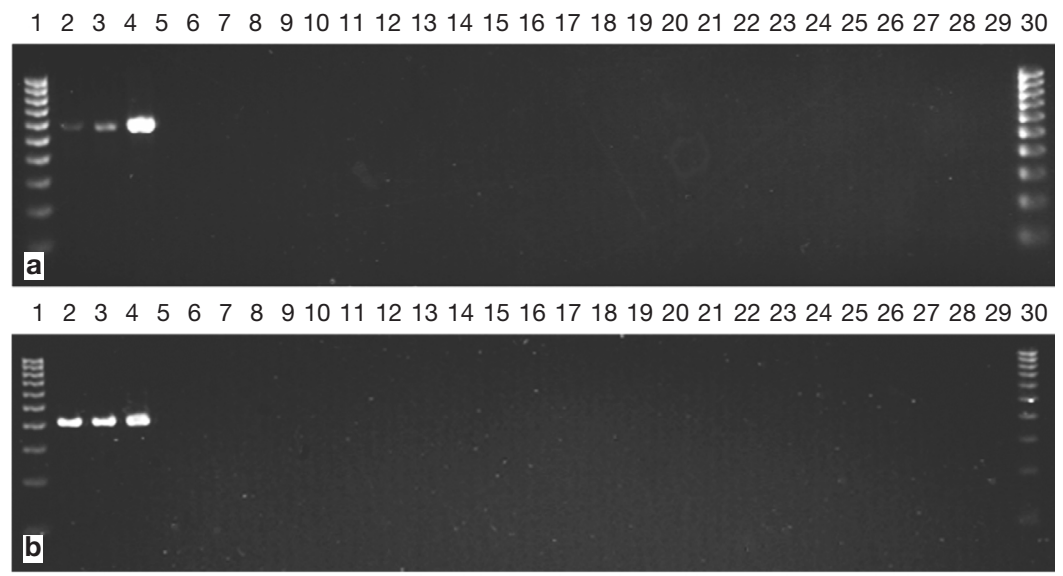

Fig. 1. Primer-pair specificity assay for (a) Nereocystis luetkeana F/R2 and (b) Hedophyllum sessile F2/R2. (a) Lanes 1 and 30: 100 bp marker; Lanes 2 to 4: $N$. luetkeana; Lane 5: Agarum clathratum; Lane 6: Agarum fimbriatum; Lane 7: Alaria marginata; Lane 8: Alaria nana; Lane 9: Costaria costata; Lane 10: Egregia menziesii; Lane 11: Eisenia arborea; Lane 12: Hedophyllum sessile; Lane 13: Laminaria groenlandica; Lane 14: Laminaria saccharina; Lane 15: Laminaria setchellii; Lane 16: Laminaria sinclarii; Lane 17: Lessoniopsis littoralis; Lane 18: Macrocystis integrifolia; Lane 19: Pleurophycus gardneri; Lane 20: Postelsia palmaeformis; Lane 21: Pterygophora californica; Lane 22: Analipus japonicus; Lane 23: Colpomenia peregrina; Lane 24: Desmarestia aceuleata; Lane 25: Petalonia spp.; Lane 26: Sargassum muticum; Lane 27: Scytosiphon simplicissimus; Lane 28: Ulva spp.; and Lane 29: Porphyra spp. (b) Lanes 1 and 30: 100 bp marker; Lanes 2 to 4: H. sessile; Lane 5: A. clathratum; Lane 6: A. fimbriatum; Lane 7: A. marginata; Lane 8: A. nana; Lane 9: C. costata; Lane 10: E. menziesii; Lane 11: E. arborea; Lane 12: L. groenlandica; Lane 13: L. saccharina; Lane 14: L. setchellii; Lane 15: L. sinclarii; Lane 16: L. littoralis; Lane 17: M. integrifolia; Lane 18: N. luetkeana; Lane 19: P. gardneri; Lane 20: P.. palmaeformis; Lane 21: $P$. californica; Lane 22: A. japonicus; Lane 23: C. peregrina; Lane 24: D. aceuleata; Lane 25: Petalonia spp.; Lane 26: S. muticum; Lane 27: S. simplicissimus; Lane 28: Ulva spp.; and Lane 29: Porphyra spp. 


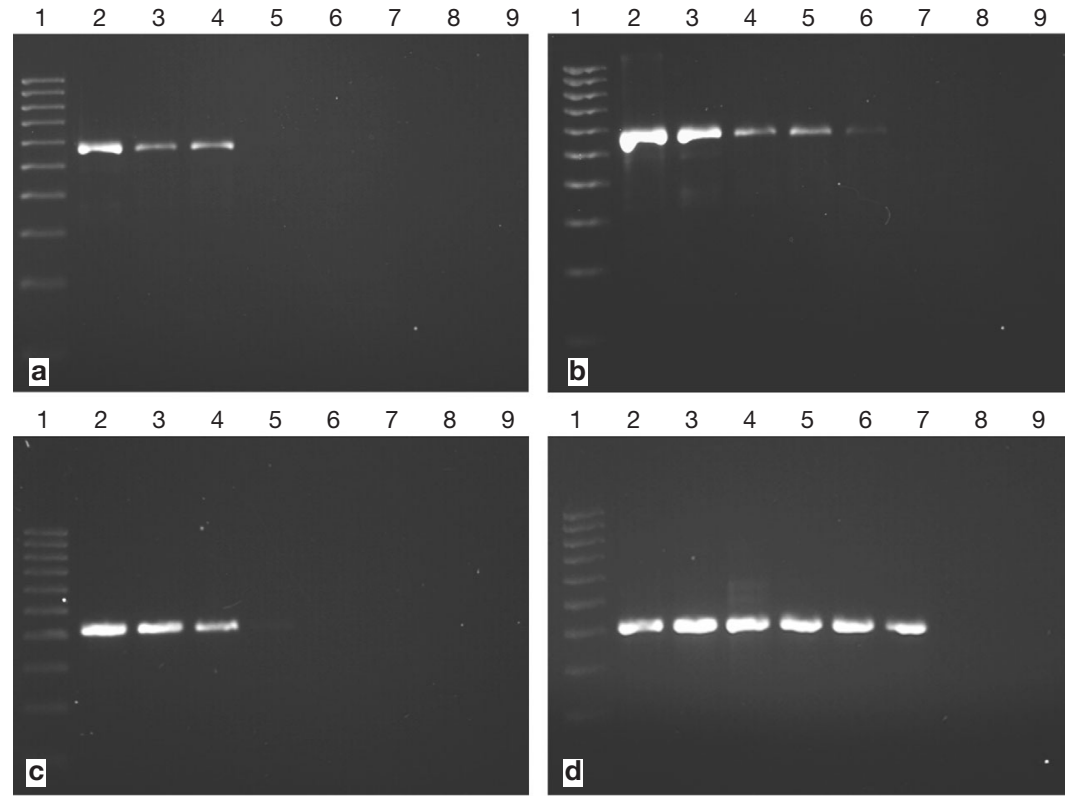

Fig. 2. Nereocystis luetkeana and Hedophyllum sessile. Detection sensitivity of gametophyte-derived $N$. luetkeana using (a) conventional unnested PCR and (b) nested PCR. Detection sensitivity of gametophyte-derived $H$. sessile using (c) conventional unnested PCR and (d) nested PCR. Lane 1: 100 bp ladder; Lane 2: $10 \mathrm{ng}$; Lane 3: $1 \mathrm{ng}$; Lane 4: 100 pg; Lane 5: 10 pg; Lane 6: 1 pg; Lane 7: $100 \mathrm{fg}$; Lane 8: $10 \mathrm{fg}$; Lane 9: $1 \mathrm{fg}$

Nereocystis luetkeana and Hedophyllum sessile, respectively (Fig. 2). Sensitivity of the nested PCR protocol for $N$. luetkeana was successful to $1 \mathrm{pg}$ DNA, whereas sensitivity for $H$. sessile was successful to $100 \mathrm{fg}$ DNA (Fig. 2). Using nested PCR, detection was possible to $1.08 \mathrm{ng}$ dried $N$. luetkeana gametophyte and 139.9 pg dried $H$. sessile gametophyte.

Species detection of putative microscopic life-stages from environmental samples resulted in PCR products of expected size or a negative result (no PCR product) (Fig. 3). All sequences retrieved from positive environmental samples in May and June confirmed species identity using NCBI BLAST searches and alignment with published sequences. Retrieved Nereocystis luetkeana sequences exhibited some base pair variability (accession numbers EF043256, EF043257 and EF043258) and the sequencing reaction did not proceed far into the ITS2 region. Retrieved Hedophyllum sessile sequences were identical (accession numbers EF043259 and EF043260).

Detection of macroscopic and putative microscopic life-stages of the 2 kelp species at Dixon Island and Bluestone Point revealed biogeographies that appeared to either closely overlap or differ markedly (Table 3). At Bluestone Point, a large (>100 individuals), exclusively Nereocystis luetkeana kelp forest existed just offshore and many individuals were reproductive (i.e. presence of sori) over the course of the study period. No macroscopic sporophytes were recorded in the intertidal zone. However, putative microscopic life-stages of $N$. luetkeana were detected from 0.0 to $3.5 \mathrm{~m}$ at Bluestone Point, although no obvious temporal or spatial relationship was detected (Table 3). Dixon Island, located ca. $3.5 \mathrm{~km}$ from Bluestone Point, hosted no offshore or proximal N. luetkeana kelp forests, although dislodged floating sporophytes frequent the area and wash onshore, providing a potentially continual propagule source. Despite the relative absence of macroscopic sporophytes of $N$. luetkeana at Dixon Island, this species was detected along the tidal height gradient from 0.0 to $3.5 \mathrm{~m}$ (Table 3). Detection was less frequent than at Bluestone Point and, again, no apparent spatial or temporal pattern was found (Table 3).

Comparisons of Hedophyllum sessile macroscopic sporophytes and putative microscopic life-stages re- a

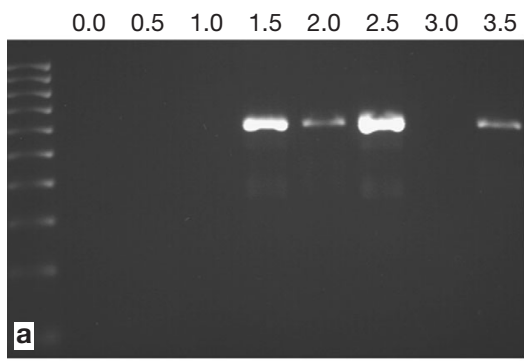

$\begin{array}{llllllll}0.0 & 0.5 & 1.0 & 1.5 & 2.0 & 2.5 & 3.0 & 3.5\end{array}$
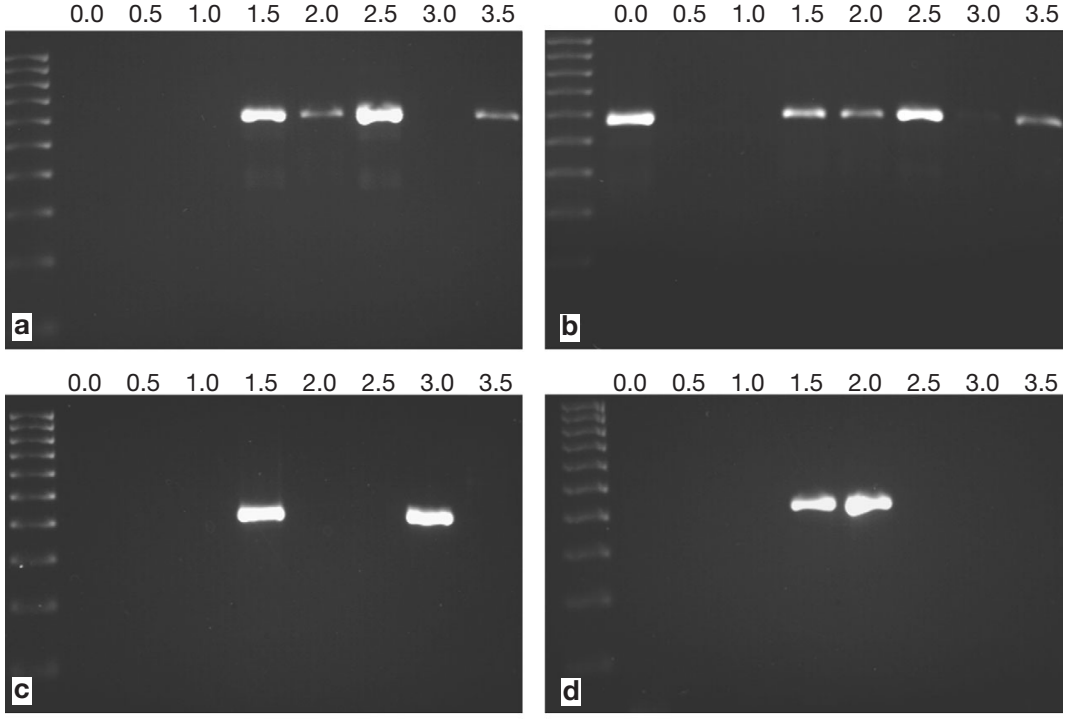

$\begin{array}{llllllll}0.0 & 0.5 & 1.0 & 1.5 & 2.0 & 2.5 & 3.0 & 3.5\end{array}$

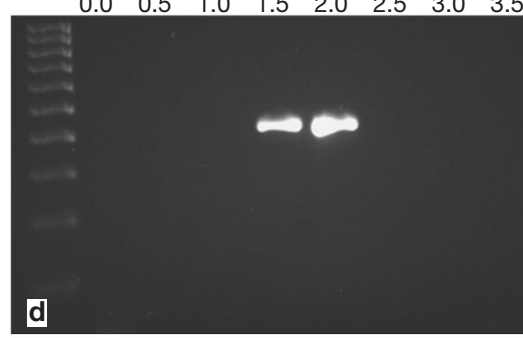

Fig. 3. Nereocystis luetkeana and Hedophyllum sessile. Detection of kelp from intertidal substrate samples collected from Bluestone Point using nested PCR. $N$. luetkeana detected in (a) May and (b) June. H. sessile detected in (c) May and (d) June. First lane: 100 bp ladder; numbers above other lanes indicate tidal height ( 0.0 to $3.5 \mathrm{~m}$ LLW) at which samples were retrieved 
Table 3. Nereocystis luetkeana and Hedophyllum sessile. Distribution of kelp macroscopic sporophytes (S) and putative microscopic life-stages (m) along intertidal height transect (0.0 to $3.5 \mathrm{~m}$ LLW) at Bluestone Point and Dixon Island, Barkley Sound, Canada in May, June, July and August 2005. ND: not done

\begin{tabular}{|c|c|c|c|c|c|c|c|c|c|c|c|c|c|c|}
\hline \multirow[t]{3}{*}{ Location } & \multicolumn{8}{|c|}{ Bluestone Point - } & \multicolumn{6}{|c|}{ Dixon Island - } \\
\hline & \multicolumn{2}{|c|}{ May } & \multicolumn{2}{|c|}{ June } & \multicolumn{2}{|c|}{ July } & \multicolumn{2}{|c|}{ August } & \multicolumn{2}{|c|}{ May } & \multicolumn{2}{|c|}{ June } & July & August \\
\hline & $\mathrm{S}$ & $\mathrm{m}$ & S & $\mathrm{m}$ & $\mathrm{S}$ & $\mathrm{m}$ & $\mathrm{S}$ & $\mathrm{m}$ & $\mathrm{S}$ & $\mathrm{m}$ & $\mathrm{S}$ & $\mathrm{m}$ & $\mathrm{S} \quad \mathrm{m}$ & $\mathrm{S} \quad \mathrm{m}$ \\
\hline N. luetkeana & & & & & & & & & & & & & & \\
\hline Subtidal & $\bullet$ & ND & - & ND & - & ND & $\bullet$ & ND & & ND & & ND & ND & ND \\
\hline & & & & $\bullet$ & & $\bullet$ & & $\bullet$ & & & & & $\bullet$ & \\
\hline 0.5 & & & & & & $\bullet$ & & - & & - & & & $\bullet$ & \\
\hline 1.0 & & & & & & - & & & & & & & - & - \\
\hline 1.5 & & - & & - & & - & & - & & & & & & \\
\hline 2.0 & & $\bullet$ & & $\bullet$ & & - & & - & & - & & - & & \\
\hline 2.5 & & $\bullet$ & & $\bullet$ & & - & & $\bullet$ & & $\bullet$ & & & & \\
\hline 3.0 & & & & $\bullet$ & & • & & $\bullet$ & & $\bullet$ & & & & \\
\hline 3.5 & & - & & $\bullet$ & & - & & & & $\bullet$ & & $\bullet$ & & $\bullet$ \\
\hline H. sessile & & & & & & & & & & & & & & \\
\hline 0.0 & & & & & & & & & & & & & & \\
\hline 0.5 & & & - & & & & - & & & & & & & \\
\hline 1.0 & - & & - & & - & & • & & & & & & & \\
\hline 1.5 & • & - & - & - & $\bullet$ & - & • & - & & & & & & \\
\hline 2.0 & & & & $\bullet$ & & - & & & & & & & & \\
\hline 2.5 & & & & & & & & & & & & & & \\
\hline 3.0 & & - & & & & & & & & & & & & \\
\hline 3.5 & & & & & & & & & & & & & & \\
\hline
\end{tabular}

vealed a markedly different pattern to that of Nereocystis luetkeana. No macroscopic sporophytes of $H$. sessile were recorded at Dixon Island and no putative microscopic life-stages were detected (Table 3), although $H$. sessile recruits nearby and macroscopic sporophytes also wash onshore. At Bluestone Point, a clearly demarcated $H$. sessile macroscopic sporophyte zone persisted and reproductive adults were observed at the site over the course of the study. Unlike N. luetkeana, $H$. sessile putative microscopic life-stages exhibited a spatial pattern that somewhat coincided with the spatial pattern of the macroscopic sporophytes (Table 3). Macroscopic sporophytes were recorded between 0.5 and $1.5 \mathrm{~m}$ tidal heights, whereas putative microscopic life-stages were detected between 1.0 and $2.0 \mathrm{~m}$ tidal heights, with one exception in May, where H. sessile was detected at $3.0 \mathrm{~m}$ (Table 3).

\section{DISCUSSION}

Similar to other reports (Grote et al. 2002, Li \& Hartman 2003, Zhang et al. 2005), our nested PCR protocol increased detection sensitivity by 100 to 1000 times over conventional, unnested PCR. However, sensitivity analyses were performed on single species gametophyte-derived DNA. The sensitivity of detection in environmental samples is likely lessened due to the presence of mixed species DNA and environmental PCR inhibitors such as humic acids (Godhe et al. 2001).
An additional advantage of nested PCR is that the presence of PCR inhibitors in the first round of PCR that hamper amplification efficiency may be reduced for second round PCR (van Tuinen et al. 1998), allowing for fewer false negatives and more robust reactions. Also, nested PCR permits the user to work with first round PCR products instead of often limited amounts of crude DNA extracts, which in turn permits additional analyses.

Similar to studies of fungal diversity in soils where PCR-based molecular tools cannot discriminate between active, established fungi and inactive dormant forms (Bridge \& Spooner 2001), this protocol cannot discriminate between recently settled zoospores that will not survive and gametophytes or microscopic sporophytes that have survived and established. Further, with large populations of macroscopic sporophytes in the study area, such as the large population of Nereocystis luetkeana at Bluestone Point, there is also potential for the detection of microscopic fragments of sporophyte tissues containing sufficiently intact DNA. In this study, detection of $N$. luetkeana at Dixon Island, where attached macroscopic sporophytes are absent, suggests that microscopic life-stages were likely responsible for positive results. Similarly, at the wave-exposed Bluestone Point site, fragments of the macroscopic sporophytes were likely dispersed throughout the intertidal, yet detected Hedophyllum sessile putative microscopic life-stages were somewhat spatially coupled to the limited distributions of the macroscopic sporophyte. 
The distribution of putative microscopic life-stages of Nereocystis luetkeana at Bluestone Point and Dixon Island indicates that these life-stages are widespread in the intertidal, unlike the macroscopic sporophyte, which is almost exclusively subtidal. Such a distribution suggests that propagules are settling frequently throughout the intertidal and/or are able to survive in the low to high intertidal. Evidence suggests that it is unlikely that $N$. luetkeana microscopic life-stages would survive for long in the high intertidal, especially during summer months, given the relatively high UV exposure, desiccation and temperature stress. Previous research has established that $N$. luetkeana gametophytes and young sporophytes are sensitive to temperature (Vadas 1972). Further, a number of Laminariales microscopic life-stages have demonstrated sensitivities to UV exposure (Dring et al. 1996, Swanson \& Druehl 2000, Wiencke et al. 2000, 2004, 2006) which increases with tidal height (Swanson 2000). One explanation for the observed widespread distribution of putative microscopic life-stages of $N$. luetkeana is that propagule dispersal occurred during the most recent tide and substrates were then sampled in early morning, before light, heat and desiccation stresses were maximal. Long distance transport of propagules is a potential explanation for the detection of putative microscopic life-stages at Dixon Island since dispersal and recruitment at distances of $500 \mathrm{~m}$ have been previously recorded for kelp (Reed et al. 1988). Zoospore release by reproductive rafting $N$. luetkeana, dislodged from large $N$. luetkeana kelp forests nearby, is another possible source of colonization. As wave action is a primary factor dislodging buoyant sporophytic $N$. luetkeana, the abundance of microscopic life-stages might be expected to decrease seasonally at the Dixon Island site, with the corresponding decrease in seasonal storm intensity and frequency; however, this pattern was not observed. Additionally, the detection of putative microscopic life-stages of $N$. luetkeana at Dixon Island may indicate the presence of accumulated microscopic life-stages, forming hypothesized banks of microscopic forms (e.g. Chapman 1986).

Unlike Nereocystis luetkeana, macroscopic and microscopic Hedophyllum sessile life-stages shared a similarly restricted distribution. With one exception, both macroscopic and putative microscopic life-stages generally occurred in the mid-intertidal. No microscopic life-stages of $H$. sessile were detected at Dixon Island, indicating that $H$. sessile zoospores may be more limited in their dispersal or survival ability, or occurred in abundances below the limits of detection. Of 6 kelp species examined, H. sessile was found to have the largest average zoospores and exhibited less inhibition by UV-B than deeper water kelp (Swanson \& Druehl 2000). This relative tolerance to UV-B may contribute to the discerned upper limit of both macroscopic and putative microscopic $H$. sessile described in our study. Detection of putative microscopic life-stages in summer also advances the possibility that these forms may persist until environmental conditions improve, potentially many months later, given that $H$. sessile sporophyte recruitment generally occurs in late winter and spring (Milligan 1998).

Assays for detecting putative microscopic life-stages of 2 common kelp species, Nereocystis luetkeana and Hedophyllum sessile, on natural substrates were developed and utilized to compare vertical distributions of putative microscopic and macroscopic life-stages. This research is the first to directly compare putative microscopic life-stage distributions of kelp species with macroscopic sporophyte distributions, historically the primary focus of numerous kelp studies. The combined use of this molecular detection protocol with traditional macroscopic sporophyte surveys and controlled experiments to evaluate life-stage sensitivities to abiotic and biotic variables will allow for the testing of long-standing ecological hypotheses pertaining to Laminariales vertical distributions and mechanisms of persistence in variable environments. More complete investigations are required to assess the underlying ecologies of microscopic life-stages and their influences on kelp species and associated ecosystems.

Acknowledgements. The authors are indebted to M. Edwards and 4 anonymous reviewers for their valuable comments. We thank G. Saunders, C. Lane, L. Druehl, R. Lewis, C. Cullis and $H$. Kucera for information and advice. We are grateful to the Huu-Ay-Aht First Nation for territory access, Bamfield Marine Sciences Centre, and R. Davey, J. Mersereau, M. Berger, S. Carrino and S. Dudas for field assistance.

\section{LITERATURE CITED}

Anderson RJ (1982) The life history of Desmarestia firma (C. Ag.) Skottsb. (Phaeophyceae, Desmarestiales). Phycologia 21(3):316-322

Antoine E, Fleurence J (2003) Species identification of red and brown seaweeds using ITS ribosomal DNA amplification and RFLP patterns. J Sci Food Agric 83:709-713

Ausubel FM, Brent R, Kingston RE, Moore DD, Siedman JG, Smith JA, Struhl K (eds) (1987) Current protocols in molecular biology supplement 27. Wiley Interscience, New York

Blanchette CA (1996) Seasonal patterns of disturbance influence recruitment of the sea palm, Postelsia palmaeformis. J Exp Mar Biol Ecol 197:1-14

Bridge P, Spooner B (2001) Soil fungi: diversity and detection. Plant Soil 232:147-154

Chapman ARO (1986) Population and community ecology of seaweeds. In: Baxter JHS, Southwood AJ (eds) Advances in marine biology. Academic Press, London, p 1-161

Dayton PK (1985) Ecology of kelp communities. Annu Rev Ecol Syst 16:215-245

Deagle BE, Bax N, Hewitt CL, Patil JG (2003) Development and evaluation of a PCR-based test for detection of 
Asterias (Echinodermata: Asteroidea) larvae in Australian plankton samples from ballast water. Mar Freshw Res 54(6):709-719

Doyle JJ, Doyle JL (1990) Isolation of plant DNA from fresh tissue. Focus 12:13-15

Dring MJ, Makarov V, Schoschina E, Lorenz M, Lüning K (1996) Influence of ultraviolet-radiation on chlorophyll fluorescence and growth in different life-history stages ofthree species of Laminaria (phaeophyta). Mar Biol 126: 183-191

Druehl LD, Hsiao IC (1977) Intertidal kelp response to seasonal environmental changes in a British Columbia inlet. J Fish Res Board Can 34:1207-1211

Druehl LD, Collins JD, Lane CE, Saunders GW (2005) A critique of intergeneric kelp hybridization protocol, employing Pacific Laminariales (Phaeophyceae). J Phycol 41: $250-262$

Edwards MS (2000) The role of alternate life-history stages of a marine macroalga: a seed bank analogue? Ecology 81(9): $2404-2415$

Foster MS, Schiel DR (1985) The ecology of giant kelp forests: a community profile. Biological Report. US Fish and Wildlife Service Biological Report 85 (7.2)

Garbary DJ, Kim KY, Klinger T, Duggins D (1999) Preliminary observations on the development of kelp gametophytes endophytic in red algae. Hydrobiologia 398/399:247-252

Godhe A, Otta SK, Rehnstam-Holm AS, Karunasagar I, Karunasagar I (2001) Polymerase chain reaction in detection of Gymnodinium mikimotoi and Alexandrium minutum in field samples from southwest India. Mar Biotechnol 3(2): 152-162

Graham MH (1996) Effect of high irradiance on recruitment of the giant kelp Macrocystis (Phaeophyta) in shallow water. J Phycol 32(6):903-906

Graham MH (1999) Identification of kelp zoospores from in situ plankton samples. Mar Biol 135:709-720

Graham MH, Mitchell BG (1999) Obtaining absorption spectra from individual macroalgal spores using microphotometry. Hydrobiologia 398/399:231-239

Grote D, Olmos A, Kofoet A, Tuset JJ, Bertolini E, Cambra M (2002) Specific and sensitive detection of Phytophthora nicotianae by simple and nested-PCR. Eur J Plant Pathol 108:197-207

Hoffmann AJ, Santelices B (1991) Banks of algal microscopic forms: hypotheses on their functioning and comparisons with seed banks. Mar Ecol Prog Ser 79:185-194

Hsiao SIC, Druehl LD (1973) Environmental control of gametogenesis in Laminaria saccharina. IV. In situ development of gametophytes and young sporophytes. J Phycol 9:160-164

Kinlan BP, Graham MH, Sala E, Dayton PK (2003) Arrested development of giant kelp (Macrocystis pyrifera, Phaeophyceae) embryonic sporophytes: a mechanism for delayed recruitment in perennial kelps? J Phycol 39:47-57

Ladah LB, Zertuche-González JA, Hernández-Carmona G (1999) Giant kelp (Macrocystis pyrifera, Phaeophyceae) recruitment near its southern limit in Baja California after mass disappearance during ENSO 1997-1998. J Phycol 35: 1106-1112

Lane CE, Saunders GW (2005) Molecular investigation reveals epi/endophytic extrageneric kelp (Laminariales, Phaeophyceae) gametophytes colonizing Lessoniopsis littoralis thalli. Bot Mar 48:426-436

Li S, Hartman GL (2003) Molecular detection of Fusarium solanif. sp. glycines in soybean roots and soil. Plant Pathol $52: 74-83$

Milligan KLD (1998) Effects of wave-exposure on an intertidal kelp species Hedophyllum sessile (C.Agardh) Setchell: demographics and biomechanics. PhD dissertation, University of British Columbia, Vancouver

Muller JE (1982) Geology of Nitinat Lake Area, British Columbia Map $92 \mathrm{C} / \mathrm{NE}$ and parts of C/NW and C/SE, 1st Status edn. Geological Survey of Canada

Patil JG, Gunasekera RM, Deagle BE, Bax NJ, Blackburn SI (2005) Development and evaluation of a PCR based assay for detection of the toxic dinoflagellate, Gymnodinium catenatum (Graham) in ballast water and environmental samples. Biol Invasions 7:983-994

Reed DC (1990) The effects of variable settlement and early competition on patterns on kelp recruitment. Ecology 71(2):776-787

Reed DC, Laur DR, Ebeling AW (1988) Variation in algal dispersal: the importance of episodic events. Ecol Monogr 58(4):321-335

Reed DC, Anderson TW, Ebeling AW, Anghera M (1997) The role of reproductive synchrony in the colonization potential of kelp. Ecology 78(8):2443-2457

Roleda MY, Wiencke C, Hanelt D, van de Poll WH, Gruber A (2005) Sensitivity of Laminariales zoospores from Helgoland (North Sea) to ultraviolet and photosynthetically active radiation: implications for depth distribution and seasonal reproduction. Plant Cell Environ 28:466-479

Santelices B (1990) Patterns of reproduction, dispersal and recruitment in seaweeds. Oceanogr Mar Biol Annu Rev 28:177-276

Santelices B, Hoffmann AJ, Aedo D, Bobadilla M, Otaíza R (1995) A bank of microscopic forms on disturbed boulders and stones in tide pools. Mar Ecol Prog Ser 129:215-228

Schiel MR, Foster DS (1986) The structure of subtidal algal stands in temperature waters. Oceanogr Mar Biol Annu Rev 24:265-307

Setchell WA, Gardner NL (1925) The marine algae of the pacific coast of America. University of California Press, Berkeley, CA

Steneck RS, Graham MH, Bourque BJ, Corbett D, Erlandson JM, Estes JA, Tegner MJ (2002) Kelp forest ecosystems: biodiversity, stability, resilience and future. Environ Conserv 29(4):436-459

Swanson AK (2000) Ecophysiological adaptations of Northeast Pacific kelp communities to ultraviolet light stress. PhD dissertation, Simon Fraser University, Burnaby

Swanson AK, Druehl LD (2000) Differential meiospore size and tolerance of ultraviolet stress within and among kelp species along a depth gradient. Mar Biol 136:657-664

Tai V, Lindstrom SC, Saunders GW (2001) Phylogeny of the Dumontiaceae (Gigartinales, Rhodophyta) and associated families based on SSU rDNA and internal transcribed spacer sequence data. J Phycol 37:184-196

Vadas R (1972) Ecological implications of culture studies on Nereocystis luetkeana. J Phycol 8:196-203

Van der Flier-Keller E, McMillan WJ (1987) The identification of common rocks. Mineral Resources Division, Geological Survey Branch, Ministry of Energy, Mines and Petroleum Resources, Province of British Columbia

van Hannen EJ, van Agterveld MP, Gons HJ, Laanbroek HJ (1998) Revealing genetic diversity of eukaryotic microorganisms in aquatic environments by denaturing gradient gel electrophoresis. J Phycol 34:206-213

van Hannen EJ, Zwart G, van Agterveld MP, Gons HJ, Ebert J, Laanbroek HJ (1999) Changes in bacterial and eukaryotic community structure after mass lysis of filamentous cyanobacteria associated with viruses. Appl Environ Microbiol 65(2):795-801

Van Tuinin D, Jacquot E, Zhao B, Gollotte A, Gianinazzi- 
Pearson V (1998) Characterization of root colonization profiles by a microcosm community of arbuscular mycorrhizal fungi using 25S rDNA-targeted nested PCR. Mol Ecol 7:879-887

Wiencke C, Gómez I, Pakker H, Flores-Moya A, Altamirano M, Hanelt D, Bischof K, Figueroa FL (2000) Impact of UVradiation on viability, photosynthetic characteristics and DNA of brown algal zoospores: implications for depth zonation. Mar Ecol Prog Ser 197:217-229

Wiencke C, Clayton MN, Schoenwaelder M (2004) Sensitivity

Editorial responsibility: Otto Kinne (Editor-in-Chief), Oldendorf/Luhe, Germany and acclimation to UV radiation of zoospores fromfive species of Laminariales from the Arctic. Mar Biol 145(1):31-39 Wiencke C, Roleda MY, Gruber A, Clayton MN, Bischof K (2006) Susceptibility of zoospores to UV radiation determines upper depth distribution limit of Arctic kelps: evidence through field experiments. J Ecol 94:455-463

Zhang Z, Zhang J, Wang Y, Zheng X (2005) Molecular detection of Fusarium oxysporum f. sp. Niveum and Mycosphaerella melonis in infected plant tissues and soil. FEMS Microbiol Lett 249:39-47

Submitted: October 19, 2006; Accepted: January 17, 2007 Proofs received from author(s): February 4, 2007 